\title{
SOME POSTURAL ADJUSTMENTS OF SALT AND WATER EXCRETION ${ }^{1,2}$
}

\author{
By MORTON LEE PEARCE ${ }^{8}$ and ELLIOT V. NEWMAN WITH THE assistaNCE OF \\ MARION R. BIRMINGHAM \\ (From the Department of Medicine, Vanderbilt University School of Medicine, \\ Nashville, Tenn.)
}

(Submitted for publication October 6, 1953; accepted April 17, 1954)

Among the acute adjustments of the normal human to orthostatic posture is a diminution in the rate of excretion of water and certain electrolytes $(2,3)$. This is associated with variable reductions of renal plasma flow and glomerular filtration rate $(2,4)$ and may actually occur without any appreciable change in the latter (3). The changes in renal hemodynamics are related to a fall in blood pressure and cardiac output which usually follows the assumption of upright posture $(5,6)$.

The causal sequence leading to orthostatic antidiuresis and antisaluresis is unknown. In acute experiments Pitressin administration leads to water retention without antisaluresis (7). That antisaluresis may occur without antidiuresis is less clear, although there is evidence that it may occur during alcohol diuresis $(8,9)$ which probably works through depression of the supraoptic posterior pituitary system. It also apparently occurs in venous congestion of the limbs in patients with diabetes insipidus (10). Orthostatic antisaluresis is reported to have been blocked by neck constriction (11) and legwrapping (12). Hypotonic expansion of the extracellular fluid volume in hydrated recumbent subjects results in increased sodium excretion (13). On the other hand, the administration of hyperoncotic albumin solutions results in diminished sodium excretion (14). In this instance antisaluresis is related to antidiuresis and is at least partially independent of the posterior pituitary since it occurs in patients with diabetes insipidus (15).

It was the purpose of the experiments reported here to investigate the effect on salt and water excretion of upright posture complicated as little

1 A preliminary report appeared in abstract form (1).

2 Aided in part by a grant from the Life Insurance Medical Research Fund.

${ }^{8} \mathrm{G}$. D. Searle Fellow in Experimental Medicine. Present address : University of California Medical School, Los Angeles 24, California. as possible by vasomotor changes. An attempt was also made to determine whether the antidiuresis and the antisaluresis of standing are interdependent or controlled by separate mechanisms. To this end three sets of experiments were performed. In the first the effect of standing on salt and water excretion was measured. In the second an attempt was made to inhibit the secretion of Pitressin by administering alcohol to the subjects. In the third set of experiments legwrapping was employed to inhibit postural antisaluresis. The results obtained in the last two sets of experiments were compared with the first, using each subject as his own control.

\section{METHODS}

The subjects were normal adult laboratory personnel and medical students. No attempt was made to control the diet over the days preceding the experiments. The experiments were done in the morning with the subjects fasting. Upon arising in the morning the subjects emptied their bladders, noted the time and ingested 250 to $400 \mathrm{cc}$. of water. Upon arrival at the laboratory they again voided $\left(U_{1}\right)$ and then rested supine. Voided urine was collected every 20 minutes and $150 \mathrm{cc}$. of water were ingested after each urine collection. After water diuresis had been established (one to two hours), the subjects were tilted to $60^{\circ}$ from the horizontal position for one hour. To avoid marked shifts in fluid compartments and vasomotor effects the subjects were encouraged to shift their legs occasionally during this hour. Following the orthostatic period, urine collections were made for another hour with the subject supine. The experimental period was thus bracketed by two control periods. This was considered important because of known fluctuations in salt and water excretion during various hours of the day, and from day to day. The experiments were performed in a quiet room with only essential personnel entering and leaving the room. Smoking was interdicted because of the antidiuretic and vasomotor effects associated with it.

In the experiments in which alcohol was administered, $25 \mathrm{cc}$. of 95 per cent ethanol and $125 \mathrm{cc}$. of grapefruit juice were substituted for the $150 \mathrm{cc}$. of water ingested at the time of tilting and 20 minutes before it. This is 
TABLE I

Control experiments

\begin{tabular}{|c|c|c|c|c|c|c|c|c|c|c|c|c|c|c|c|}
\hline \multirow[b]{2}{*}{ Subject } & \multicolumn{5}{|c|}{ Control period preceding tilt } & \multicolumn{5}{|c|}{ Maximum tilt effect } & \multicolumn{5}{|c|}{ Last period of second control } \\
\hline & $\begin{array}{l}\text { Creati- } \\
\text { nine } \\
\text { clear- } \\
\text { ance }\end{array}$ & $\begin{array}{l}\text { Urine } \\
\text { ml./ } \\
\text { min. }\end{array}$ & $\underset{\min }{\mathrm{Na}}$ & $\underset{\text { min. }}{\mathrm{Cl}}$ & $\underset{\substack{\min . \\
E q . /}}{\mathrm{K}}$ & $\begin{array}{l}\text { Creati- } \\
\text { nine } \\
\text { clear- } \\
\text { ance }\end{array}$ & $\begin{array}{l}\text { Urine } \\
\text { ml./ } \\
\text { min. }\end{array}$ & $\underset{\text { min. }}{\mathrm{Na}}$ & $\underset{\substack{\min \\
\mathrm{Eq} . /}}{\mathrm{Cl}}$ & $\underset{\min .}{\mathrm{K}}$ & $\begin{array}{c}\text { Creati- } \\
\text { nine } \\
\text { clear- } \\
\text { ance }\end{array}$ & $\begin{array}{l}\text { Urine } \\
\text { ml./ } \\
\text { min. }\end{array}$ & $\underset{\text { min. }}{\mathbf{N a}}$ & $\underset{\min }{\mathrm{Cl}} \underset{\text { me./ }}{\mathrm{Cl}}$ & $\underset{\min .}{\mathrm{K}}$ \\
\hline $\begin{array}{l}\text { M. L. P. } \\
\text { M. B. } \\
\text { M. B. } \\
\text { C. M. } \\
\text { E. V. N. } \\
\text { D. McC. } \\
\text { M. Y. }\end{array}$ & $\begin{array}{r}121 \\
119 \\
107 \\
111 \\
83 \\
96 \\
96\end{array}$ & $\begin{array}{l}13.0 \\
13.2 \\
14.1 \\
11.8 \\
13.0 \\
11.7 \\
12.3\end{array}$ & $\begin{array}{l}.191 \\
.112 \\
.177 \\
.348 \\
.208 \\
.102 \\
.180\end{array}$ & $\begin{array}{l}.156 \\
.092 \\
.226 \\
.339 \\
.180 \\
.106 \\
.226\end{array}$ & $\begin{array}{l}.110 \\
.106 \\
.153 \\
.159 \\
.107 \\
.117 \\
.049\end{array}$ & $\begin{array}{r}125 \\
101 \\
97 \\
100 \\
70 \\
87 \\
84\end{array}$ & $\begin{array}{l}3.1 \\
2.36 \\
4.5 \\
2.45 \\
4.75 \\
6.6 \\
6.1\end{array}$ & $\begin{array}{l}.063 \\
.040 \\
.082 \\
.105 \\
.045 \\
.053 \\
.090\end{array}$ & $\begin{array}{l}.053 \\
.065 \\
.115 \\
.147 \\
.082 \\
.076 \\
.142\end{array}$ & $\begin{array}{l}.029 \\
.066 \\
.052 \\
.078 \\
.064 \\
.077 \\
.020\end{array}$ & $\begin{array}{r}152 \\
111 \\
108 \\
109 \\
81 \\
101 \\
83\end{array}$ & $\begin{array}{r}13.3 \\
16.0 \\
14.2 \\
11.0 \\
10.2 \\
13.0 \\
6.7\end{array}$ & $\begin{array}{l}.143 \\
.176 \\
.250 \\
.284 \\
.179 \\
.147 \\
.154\end{array}$ & $\begin{array}{l}.101 \\
.138 \\
.195 \\
.276 \\
.144 \\
.151 \\
.181\end{array}$ & $\begin{array}{l}.086 \\
.140 \\
.137 \\
.143 \\
.089 \\
.139 \\
.088\end{array}$ \\
\hline
\end{tabular}

TABLE II

Experiments in which alcohol was given before tilt

\begin{tabular}{|c|c|c|c|c|c|c|c|c|c|c|c|c|c|c|c|}
\hline \multirow[b]{2}{*}{ Subject } & \multicolumn{5}{|c|}{ Control period preceding tilt } & \multicolumn{5}{|c|}{ Maximum tilt effect } & \multicolumn{5}{|c|}{ Last period of second control } \\
\hline & $\begin{array}{l}\text { Creati- } \\
\text { nine } \\
\text { clear- } \\
\text { ance }\end{array}$ & $\begin{array}{l}\text { Urine } \\
\text { mi./ } \\
\text { min. }\end{array}$ & $\underset{\text { min. }}{\text { Na }}$ & $\underset{\text { min. }}{\mathrm{Cl}}$ & 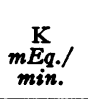 & $\begin{array}{l}\text { Creati- } \\
\text { nine } \\
\text { clear- } \\
\text { ance }\end{array}$ & $\begin{array}{l}\text { Urine } \\
\text { mi./ } \\
\text { min. }\end{array}$ & $\underset{m \in \mathbf{N a}}{\min .}$ & $\underset{m \in \mathbf{E}}{\mathbf{C l}}$ & $\underset{\text { min. }}{\mathbf{K}}$ & $\begin{array}{l}\text { Creati- } \\
\text { nine } \\
\text { clear- } \\
\text { ance }\end{array}$ & $\begin{array}{l}\text { Urine } \\
\text { ml./ } \\
\text { min. }\end{array}$ & $\underset{m}{\text { Na }} \underset{\text { min. }}{\text { min. }}$ & $\underset{m i n}{\mathbf{C l}}$ & $\underset{\min .}{\mathbf{K}}$ \\
\hline $\begin{array}{l}\text { M. L. P. } \\
\text { M. B. } \\
\text { C. M. } \\
\text { D. McC. } \\
\text { M. Y. }\end{array}$ & $\begin{array}{r}144 \\
113 \\
125 \\
87 \\
115\end{array}$ & $\begin{array}{l}11.8 \\
10.8 \\
13.2 \\
11.6 \\
15.7\end{array}$ & $\begin{array}{l}.200 \\
.121 \\
.371 \\
.123 \\
.210\end{array}$ & $\begin{array}{l}.212 \\
.111 \\
.360 \\
.131 \\
.227\end{array}$ & $\begin{array}{l}.254 \\
.070 \\
.138 \\
.055 \\
.047\end{array}$ & $\begin{array}{r}111 \\
101 \\
119 \\
87 \\
111\end{array}$ & $\begin{array}{r}10.7 \\
10.5 \\
7.2 \\
13.0 \\
11.8\end{array}$ & $\begin{array}{l}.068 \\
.040 \\
.057 \\
.065 \\
.080\end{array}$ & $\begin{array}{l}.058 \\
.052 \\
.073 \\
.078 \\
.107\end{array}$ & $\begin{array}{l}.081 \\
.034 \\
.036 \\
.019 \\
.014\end{array}$ & $\begin{array}{r}126 \\
104 \\
100 \\
84 \\
116\end{array}$ & $\begin{array}{c}11.4 \\
13.6 \\
8.7 \\
2.75 \\
12.4\end{array}$ & $\begin{array}{l}.125 \\
.101 \\
.124 \\
.137 \\
.152\end{array}$ & $\begin{array}{l}.089 \\
.079 \\
.110 \\
.143 \\
.149\end{array}$ & $\begin{array}{l}.091 \\
.134 \\
.044 \\
.032 \\
.088\end{array}$ \\
\hline
\end{tabular}

TABLE III

Experiment in which alcohol was given but subject remained supine through usual tilt period

\begin{tabular}{|c|c|c|c|c|c|c|}
\hline \multirow[b]{2}{*}{ Subject } & \multicolumn{2}{|c|}{ Control period preceding tilt } & \multicolumn{2}{|r|}{ Maximum tilt effect } & \multicolumn{2}{|c|}{ Last period of second control } \\
\hline & $\begin{array}{l}\text { Creati- } \\
\text { nine } \\
\text { clear- } \\
\text { ance }\end{array}$ & $\underset{\text { ml./ }}{\text { Urine }} \underset{\text { min. }}{\mathrm{Na}} \underset{\text { min./ ma }}{\mathrm{Na}} \underset{\text { min. }}{\mathrm{Cl}} \underset{\text { min. }}{\mathrm{K}} \underset{\text { min. }}{\mathrm{K}}$ & $\begin{array}{l}\text { Creati- } \\
\text { nine } \\
\text { clear- } \\
\text { ance }\end{array}$ & $\underset{\text { ml./ }}{\text { Urine }} \underset{\text { min. }}{\operatorname{maq}} \underset{\text { min. }}{\mathrm{Na}} \underset{\text { me./. }}{\mathrm{Cl}} \underset{\text { min. }}{\mathrm{mEq}} \underset{\text { min. }}{\mathrm{K}}$ & $\begin{array}{l}\text { Creati- } \\
\text { nine } \\
\text { clear- } \\
\text { ance }\end{array}$ & 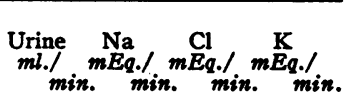 \\
\hline M. L.P. & 148 & $\begin{array}{llll}13.5 & .179 & .166 & .128\end{array}$ & 140 & $\begin{array}{llll}15.8 & .126 & .128 & .052\end{array}$ & 130 & $\begin{array}{lll}130 & .105 & .042\end{array}$ \\
\hline
\end{tabular}

TABLE IV

Experiments in which legs were wrapped before tilt

\begin{tabular}{|c|c|c|c|c|c|c|c|c|c|c|c|c|c|c|c|}
\hline \multirow[b]{2}{*}{ Subject } & \multicolumn{5}{|c|}{ Control period preceding tilt } & \multicolumn{5}{|c|}{ Maximum tilt effect } & \multicolumn{5}{|c|}{ Last period of second control } \\
\hline & $\begin{array}{l}\text { Creati- } \\
\text { nine } \\
\text { clear- } \\
\text { ance }\end{array}$ & $\begin{array}{l}\text { Urine } \\
\text { ml./ } \\
\text { min. }\end{array}$ & $\underset{\substack{\operatorname{mag} \\
\min . /}}{\mathrm{Na}}$ & $\underset{\text { min. }}{\mathrm{Cl}}$ & 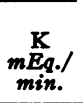 & $\begin{array}{l}\text { Creati- } \\
\text { nine } \\
\text { clear- } \\
\text { ance }\end{array}$ & $\begin{array}{l}\text { Urine } \\
\text { ml./ } \\
\text { min. }\end{array}$ & $\underset{\substack{\mathrm{Na} \\
\min . /}}{ }$ & $\underset{\text { min. }}{\mathrm{Cl}}$ & $\underset{\min .}{\mathbf{K}}$ & $\begin{array}{l}\text { Creati- } \\
\text { nine } \\
\text { clear- } \\
\text { ance }\end{array}$ & $\begin{array}{l}\text { Urine } \\
\text { ml./ } \\
\text { min. }\end{array}$ & $\underset{\substack{\mathrm{maq} . \\
\text { min. }}}{\mathrm{Na}}$ & $\underset{\text { min. }}{\mathrm{Cl}}$ & $\underset{\min .}{\mathbf{K}}$ \\
\hline $\begin{array}{l}\text { M. L. P. } \\
\text { M. L. P. } \\
\text { M. B. } \\
\text { C. M. } \\
\text { C. M. } \\
\text { E. V. N. } \\
\text { E. V. N. } \\
\text { D. McC. } \\
\text { M. Y. }\end{array}$ & $\begin{array}{r}137 \\
137 \\
134 \\
120 \\
109 \\
106 \\
107 \\
98 \\
98\end{array}$ & $\begin{array}{l}13.6 \\
11.5 \\
19.1 \\
13.9 \\
11.5 \\
13.7 \\
12.7 \\
12.4 \\
15.0\end{array}$ & $\begin{array}{l}.181 \\
.136 \\
.168 \\
.264 \\
.338 \\
.206 \\
.178 \\
.040 \\
.208\end{array}$ & $\begin{array}{l}.177 \\
.141 \\
.164 \\
.340 \\
.274 \\
.219 \\
.203 \\
.046 \\
.266\end{array}$ & $\begin{array}{l}.090 \\
.122 \\
.088 \\
.111 \\
.161 \\
.141 \\
.124 \\
.027 \\
.101\end{array}$ & $\begin{array}{r}117 \\
134 \\
134 \\
108 \\
104 \\
99 \\
95 \\
87 \\
83\end{array}$ & $\begin{array}{l}8.3 \\
3.9 \\
3.4 \\
6.5 \\
4.8 \\
3.65 \\
3.8 \\
9.4 \\
9.5\end{array}$ & $\begin{array}{l}.142 \\
.086 \\
.144 \\
.216 \\
.216 \\
.080 \\
.098 \\
.024 \\
.082\end{array}$ & $\begin{array}{l}.128 \\
.082 \\
.156 \\
.262 \\
.235 \\
.106 \\
.155 \\
.059 \\
.142\end{array}$ & $\begin{array}{l}.073 \\
.057 \\
.067 \\
.076 \\
.141 \\
.077 \\
.095 \\
.037 \\
.101\end{array}$ & $\begin{array}{r}127 \\
131 \\
142 \\
115 \\
98 \\
101 \\
104 \\
98 \\
92\end{array}$ & $\begin{array}{r}13.6 \\
11.6 \\
14.8 \\
10.1 \\
10.6 \\
10.2 \\
9.8 \\
7.7 \\
12.2\end{array}$ & $\begin{array}{l}.255 \\
.135 \\
.229 \\
.273 \\
.268 \\
.159 \\
.181 \\
.063 \\
.254\end{array}$ & $\begin{array}{l}.172 \\
.104 \\
.160 \\
.332 \\
.244 \\
.184 \\
.179 \\
.101 \\
.235\end{array}$ & $\begin{array}{l}.075 \\
.087 \\
.092 \\
.097 \\
.151 \\
.095 \\
.110 \\
.052 \\
.104\end{array}$ \\
\hline
\end{tabular}

equivalent to about three whiskey highballs and produced a mild degree of inebriation in the subjects.

In the experiments in which legwrapping was employed the legs were wrapped tightly with three inch "Ace" bandages from the toes to the groin just before tilting.
The bandages were removed as soon as the supine position was again assumed.

In order to avoid the effects of pain only one venipuncture was performed in most of the experiments. This is thought to be justified because changes in serum 


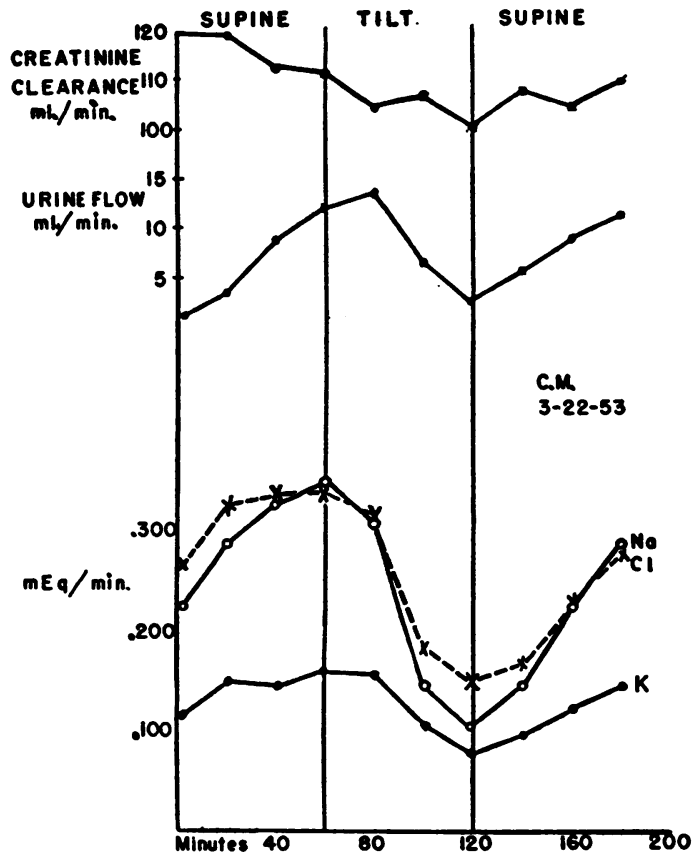

Fig. 1. The Effect of Assuming the Orthostatic Positron on Salt and Water Excretion

concentrations were slight while the changes in urinary constituents were marked.

Creatinine determinations were performed on serum and urine immediately after the experiment by the method of Peters (16). Sodium and potassium were measured

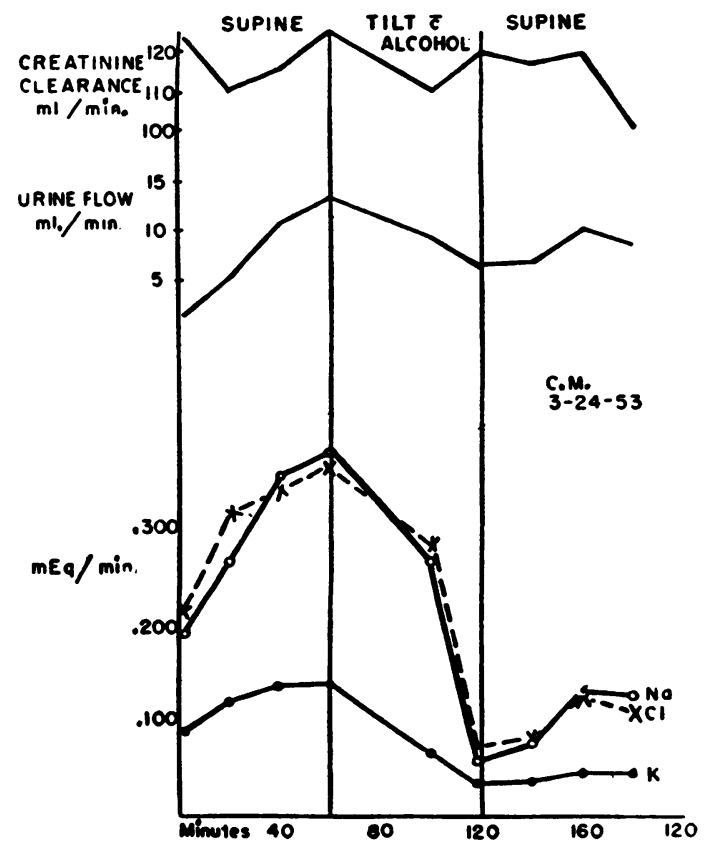

Fig. 2. The Effect of Alcohol on the Postural AdJustments of Salt and Water Excretion

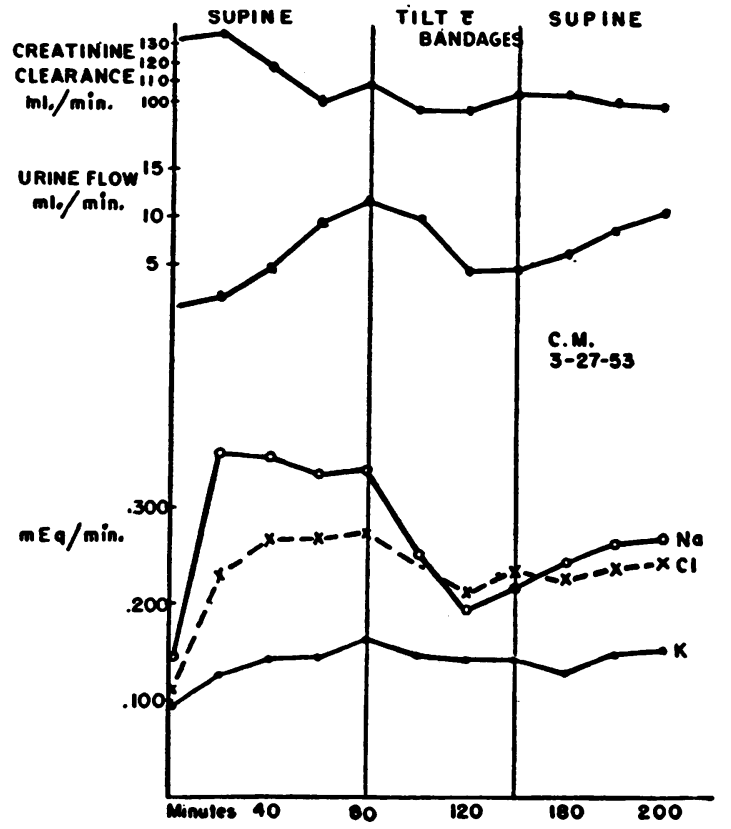

Fig. 3. The Effect of Legwrapping on the Postural Adjustments of Salt and Water Excretion

with a Beckman Model B. flame photometer. Chloride was measured by the potentiometric method of Sanderson (17).

\section{RESULTS}

Pulse and blood pressure were determined and remained fairly constant in all experiments. The means of the three groups were: Tilt alone; supine P 65, B.P. $117 / 75$, standing P 70, B.P. $120 / 83$. Alcohol experiments; supine P 61, B.P. 115/73,

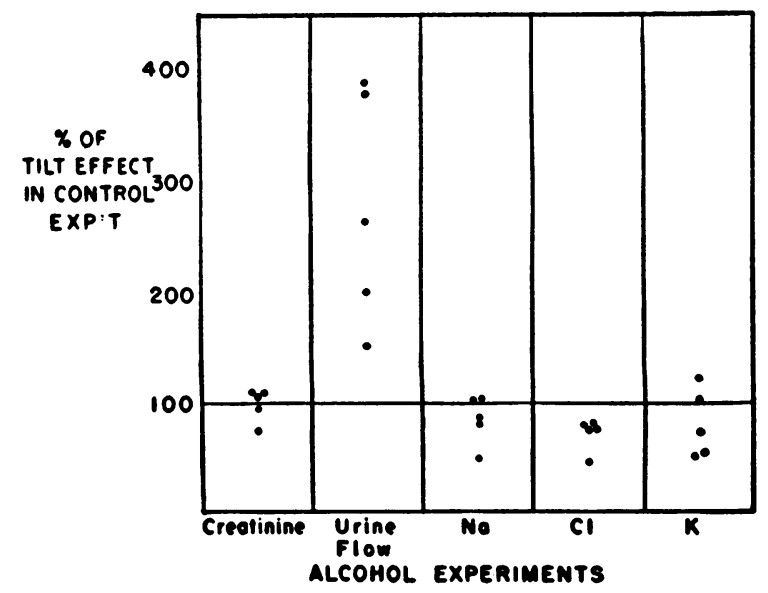

Fig. 4. The Effect of Alcohol Expressed as PerCentage of the UnComplicated Tilt Experiments Using Each Subject as His Own Control 
standing $P$ 78, B.P. 113/77. Legwrapping experiments; supine $\mathrm{P} 66, \mathrm{~B} . \mathrm{P} .121 / 78$, standing P 70, B.P. $121 / 84$.

In order to conserve space only one collection period from each control and the experimental hour is shown in Tables I to IV. The last collection of the two control periods and the experimental period in which maximum effect was noted are used. The three types of experiments on one of the subjects are shown in Figures 1-3. Table V is derived from the preceding tables by dividing each experimental result by the comparable figure in the first control so that each experimental result is expressed as a percentage of the control. Figures 4 and 5 are derived from Table V. In these figures each subject's tilt experiment served as a control for the legwrapping and alcohol experiments. The latter are expressed as percentages of the control study, i.e., (Tilt/Supine) (alcohol) $\div$ (Tilt/Supine) (Control study) $\times 100$ per cent.

In most of the experiments there was a fall in creatinine clearance to about 90 per cent of the control values. In the uncomplicated tilt experiments there was usually a greater percentage fall in water excretion than there was in electrolyte excretion so that the urine was concentrated as compared with the control period. In most of the experiments the greatest electrolyte change was in sodium and the least in potassium; chloride effect was intermediate. When alcohol was administered salt excretion fell more than in the uncomplicated tilt experiments while water excretion remained at 90 per cent of the control value on the

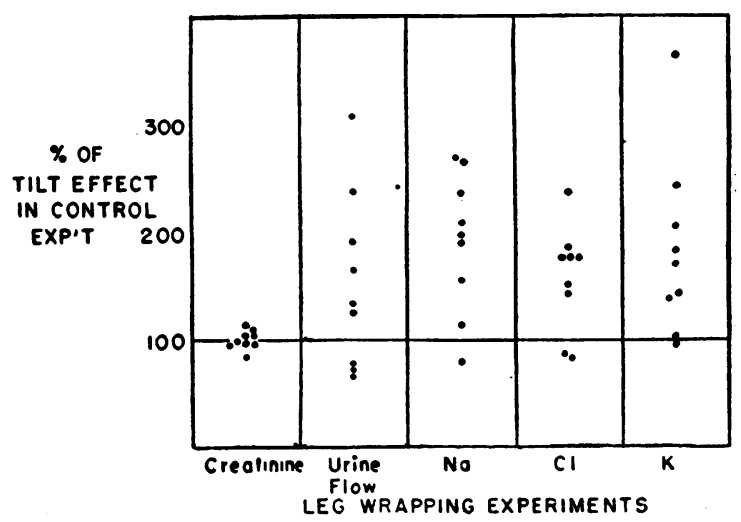

Fig. 5. The Effect of Legwrapping Expressed as IN FIGURE 4.
TABLE $\mathbf{V}$

Comparison of maximum tilt effect to control period preceding tilt

Each number represents the ratio:

$$
\frac{\text { Value in tilt period }}{\text { Value in control period }} \times 100
$$

\begin{tabular}{lccccc}
\hline \hline Subject & $\begin{array}{c}\text { Creati- } \\
\text { nine }\end{array}$ & $\begin{array}{l}\text { Urine } \\
\text { flow }\end{array}$ & Na & Cl & K \\
\hline \multicolumn{5}{c}{ A. Experiments } \\
M. with tilt alone \\
M. P. & 103 & 24 & 33 & 34 & 26 \\
M. B. & 85 & 18 & 36 & 71 & 62 \\
C. M. & 91 & 32 & 46 & 51 & 34 \\
E. V. N. & 90 & 21 & 30 & 43 & 51 \\
D. McC. & 84 & 36 & 22 & 45 & 60 \\
M. Y. & 91 & 56 & 52 & 72 & 66 \\
& 88 & 49 & 50 & 63 & 41
\end{tabular}

B. Experiments in which alcohol was given

$\begin{array}{lrrrrr}\text { M. L. P. } & 77 & 91 & 34 & 27 & 32 \\ \text { M. B. } & 90 & 97 & 33 & 47 & 49 \\ \text { C. M. } & 95 & 55 & 15 & 20 & 26 \\ \text { C. McC. } & 100 & 112 & 53 & 59 & 35 \\ \text { M. Y. } & 97 & 75 & 42 & 47 & 30\end{array}$

\section{Experiments in which legs were wrapped}

M. L.P.

M. L. P

M. B.

C. $M$.

C. $M$.

E. V.N.

E. V.N.

D. McC.

M. Y.

86
98
100
90
96
93
89
89
85

\begin{tabular}{rrrr}
61 & 79 & 72 & 81 \\
34 & 63 & $\mathbf{5 8}$ & 47 \\
18 & 86 & 93 & 76 \\
47 & 82 & 77 & 68 \\
42 & 64 & 86 & 88 \\
27 & 39 & 48 & 55 \\
30 & $\mathbf{5 5}$ & $\mathbf{7 6}$ & $\mathbf{7 7}$ \\
76 & 60 & 128 & 137 \\
$\mathbf{6 3}$ & 40 & $\mathbf{5 3}$ & 100 \\
\hline
\end{tabular}

average with production of a dilute urine. In a single experiment in which alcohol was given without the $60^{\circ}$ tilt, water excretion rose while salt excretion fell slightly during the second hour (Table III).

In some of the legwrapping experiments the expected postural antidiuresis was diminished, but this was not always the case. On the other hand, there was a consistent reduction of the expected postural antisaluresis. This effect is most noticeable when each subject's uncomplicated tilt experiment was used as control for the legwrapping experiment.

\section{DISCUSSION}

From the data it can be suggested that the mechanisms controlling salt and water excretion under the stimulus of standing can function to a large extent independently. That alcohol produced inhibition of an expected orthostatic antidiuresis suggests that this postural adaptation may 
be under supraoptic posterior pituitary control, although it may have been due in part to a suppression of antidiuretic activity existing before the tilt. The result is the converse of water retention without salt retention produced acutely by the administration of Pitressin (7).

There are several possible explanations for the reduction in postural antisaluresis produced by legwrapping. Postural antisaluresis may be produced by a stretch of veins in the lower part of the body. The increase over the control orthostatic antisaluresis in the alcohol experiments is not in agreement with this, since the blood volume is, if anything, diminished by the subsequent dehydration. The collapse of veins in the upper part of the body is a possible explanation, but the antisaluresis produced by hyperoncotic albumin (13) is not in agreement. The latter expands the intravascular space at the expense of the interstitial fluid space. The antisaluresis may be mediated in part by the fairly consistent 10 per cent fall in creatinine clearance which occurred upon standing. However, it should be noted that the fall in creatinine clearance was approximately the same whether or not the legs were wrapped. Since the postural antisaluresis was diminished following legwrapping, the fall in glomerular filtration rate is not an adequate explanation for the entire postural effect on salt excretion.

A loss of interstitial fluid from some volume sensitive area is a reasonable explanation for postural antisaluresis. Both the legwrapping and alcohol experiments support this suggestion, as do the experiments of Strauss, Davis, Rosenbaum, and Rossmeisl (13) who administered hypotonic solutions which would in part expand the interstitial space. The antisaluresis produced by hyperoncotic albumin $(14,15)$, venous compression of the legs (18) and the superior vena cava syndrome (19) are probably caused by the mechanism responsible for postural salt retention. It is difficult to reconcile the observations of Lewis, Buie, Sevier, and Harrison (11) in which it was suggested that the volume sensitive locus is in the cranium because postural antisaluresis was inhibited by neck constriction. This observation does not fit with the observations on the superior cava syndrome (19) in which intracranial venous pressure is also high. Netravisesh (20) was un- able to confirm the neck constriction experiments, and in a single experiment employing the controltilt-control protocol, neck compression failed to block the expected postural antisaluresis, although the compression was enough to produce facial edema.

Partially independent posture-sensitive mechanisms for the control of salt and water excretion seem to be present. Normally they function together and altering one of them may change the response of the other. In the light of present knowledge the best explanation is that there is some locus sensitive to the volume of the interstitial space which initiates postural antidiuresis and antisaluresis. Postural antidiuresis may be mediated through the posterior pituitary. The pathway mediating postural antisaluresis is not clear at this time.

\section{SUM MARY}

In the normal human subject undergoing moderate water diuresis quiet standing results in a slight depression of creatinine clearance and a marked depression of sodium, chloride, potassium, and water excretion as compared with control measurements in the supine position. If the legs are wrapped with elastic bandages before the orthostatic position is assumed the depression of salt excretion is inhibited with varying effect on the antidiuresis. On the other hand, administration of alcohol inhibits the orthostatic antidiuresis and enhances the orthostatic inhibition of salt excretion.

It is suggested that there are separate postural adjustments of water and salt excretion, the former under diencephalic posterior pituitary control and the latter under the control of some mechanism sensitive to the distribution of interstitial fluid.

\section{ACKNOWLEDGMENT}

We are grateful to R. B. Couch, D. McCrosky, J. Talbert, and M. Yarbrough for volunteering as subjects and helping with analyses.

\section{REFERENCES}

1. Pearce, M. L., and Newman, E. V., Some postural adjustments of salt and water excretion. J. Clin. Invest., 1953, 32, 594. 
2. Brun, C., Knudsen, E. O., and Raaschou, F., The influence of posture on the kidney function. Acta med. Scandinav., 1945, 122, 315.

3. Kattus, A. A., Sinclair-Smith, B., Genest, J., and Newman, E. V., The effect of exercise on the renal mechanism of electrolyte excretion in normal subjects. Bull. Johns Hopkins Hosp., 1949, 84, 344.

4. Ni, T-G., and Rehberg, P. B., On the influence of posture on kidney function. J. Physiol., 1931, 71, 331.

5. McMichael, J., and Sharpey-Schafer, E. P., Cardiac output in man by a direct Fick method. Effects of posture, venous pressure change, atropine and adrenaline. Brit. Heart J., 1944, 6, 33.

6. Stead, E. A., Jr., Warren, J. V., Merrill, A. J., and Brannon, E. S., The cardiac output in male subjects as measured by the technique of right atrial catheterization. Normal values with observations on the effect of anxiety and tilting. J. Clin. Invest., 1945, 24, 326.

7. Sinclair-Smith, B. C., Sisson, J., Kattus, A. A., Genecin, A., Monge, C., McKeever, W., and Newman, E. V., The effects of posterior pituitary extract and smoking on water, sodium and chloride excretion in normal subjects and in patients with congestive cardiac failure. Bull. Johns Hopkins Hosp., 1950, 87, 221.

8. Eggleton, M. G., and Smith, I. G., The effect of ethyl alcohol and some other diuretics on chloride excretion in man. J. Physiol., 1946, 104, 435.

9. Strauss, M. B., Rosenbaum, J. D., and Nelson, W. P., III, The effect of alcohol on the renal excretion of water and electrolyte. J. Clin. Invest., 1950, 29, 1053.

10. Judson, W. E., Epstein, F. H., Tinsley, C. M., Burrows, B. A., and Wilkins, R. W., The hemodynamic and renal functional effects of venous congestion of the limbs in patients with diabetes insipidus. J. Clin. Invest., 1950, 29, 826.

11. Lewis, J. M., Jr., Buie, R. M., Sevier, S. M., and Harrison, T. R., The effect of posture and of con- gestion of the head on sodium excretion in normal subjects. Circulation, 1950, 2, 822.

12. Lusk, J. A., Viar, W. N., and Harrison, T. R., Further studies on the effects of changes in the distribution of extracellular fluid on sodium excretion. Observations following compression of the legs. Circulation, 1952, 6, 911.

13. Strauss, M. B., Davis, R. K., Rosenbaum, J. D., and Rossmeisl, E. C., Production of increased renal sodium excretion by the hypotonic expansion of extracellular fluid volume in recumbent subjects. J. Clin. Invest., 1952, 31, 80.

14. Welt, L. G., and Orloff, J., The effects of an increase in plasma volume on the metabolism and excretion of water and electrolytes by normal subjects. J. Clin. Invest., 1951, 30, 751.

15. Petersdorf, R. G., and Welt, L. G., The effect of an infusion of hyperoncotic albumin on the excretion of water and solutes. J. Clin. Invest., 1953, 32, 283.

16. Peters, J. H., The determination of creatinine and creatine in blood and urine with the photoelectric colorimeter. J. Biol. Chem., 1942, 146, 179.

17. Sanderson, P. H., Potentiometric determination of chloride in biological fluids. Biochem. J., 1952 , $52,502$.

18. Judson, W. E., Hatcher, J. D., Halperin, M. H., and Wilkins, R. W., Further studies on the antidiuresis and decrease in sodium excretion during venous congestion of the limbs: its prevention in normal subjects by a large transfusion; its absence or presence in cardiac patients with or without congestive failure. J. Clin. Invest., 1952, 31, 642.

19. Rice, L., Frieden, J., Katz, L. N., Elisberg, E. I., and Rosenberg, E., A case of spontaneous thrombosis of the superior vena cava with some observations on the mechanism of edema formation. Am. Heart J., 1952, 43, 821.

20. Netravisesh, V., Effects of posture and of neck compression on outputs of water, sodium and creatinine. J. Applied Physiol., 1953, 5, 544.

\section{SPECIAL NOTICE TO SUBSCRIBERS}

Post Offices will no longer forward the Journal when you move.

Please notify The Journal of Clinical Investigation, Business Office, 622 West 168th Street, New York 32, N. Y. at once when you have a change of address, and do not omit the zone number if there is one. 